\title{
Gender and medieval archaeology: storming the castle
}

\author{
Karen Dempsey
}

Despite more than three decades of feminist critique, archaeological scholarship remains predominantly focused on the exploration of patriarchal narratives and is, therefore, complicit in reinforcing structural inequalities. Questions must be asked of how the construction of archaeological knowledge affects representation and impacts upon our 'archaeologies'. This article explores the relative absence of gendered approaches within archaeology through the lens of later medieval archaeology, with a micro-focus on castle studies in Britain and Ireland. Are there reasons for the silence in relation to gender in the archaeology of the later Middle Ages, and what lessons are there for bringing about a more inclusive archaeology?

Keywords: later medieval archaeology, castle studies, gender, feminism

\section{Introduction}

In archaeology, the story of the past is largely told through the experiences of men. There have been noticeably fewer explorations of the wider spectrum of gendered identities and ideologies that undoubtedly existed during the human past. This is perhaps not surprising given that many inequalities based on sex, sexual preference or sexual identity persist to the present day. Our versions of the past reflect the context in which archaeological knowledge is produced: a patriarchal society in which (white) men are privileged above others tends to write a past based on the supremacy of males in highly stratified cultures, mirroring their present. More surprising is that this situation persists more than 30 years after the first feminist critiques of archaeology (Conkey \& Spector 1984; Gilchrist 1991). Does this general silence about gender within the discipline of archaeology represent a backlash against feminism? Is it that feminist perspectives to the past are merely unpopular today, or are they viewed as too much of a challenge to the status quo? In a time of global feminist activism, encapsulated by movements such as '\#MeToo' and 'TimesUp', 'Everyday Sexism Project', 'Repealthe8th' and 'Musawah', this absence cannot reflect a disinterested audience. Rather, it demonstrates that archaeology is behind the times and needs to respond to contemporary global and intersectional feminist voices. This article represents a renewed call for explicit challenges to continuing androcentrism within archaeology. It reviews the evidence for gender disparity in the authorship of archaeological publications. The impact of this inequality is explored through the lens of later medieval archaeology in Britain and Ireland (the period AD 1066-1400 is discussed here), before providing a feminist critique of castle studies.

* Department of Archaeology, University of Reading, Whiteknights Box 227, Reading RG6 6AB, UK (Email: k. dempsey@reading.ac.uk)

(C) Antiquity Publications Ltd, 2019. This is an Open Access article, distributed under the terms of the Creative Commons Attribution licence (http://creativecommons.org/licenses/by/4.0/), which permits unrestricted re-use, distribution, and reproduction in any medium, provided the original work is properly cited.

ANTIQUITY 93369 (2019): 772-788

https://doi.org/10.15184/aqy.2019.13 


\section{Gender inequality and the construction of archaeological knowledge}

The gender imbalance in academia has been discussed thoroughly (see Harley 2003: 377-92; European Commission 2008; Van den Brink \& Benschop 2012: 71-92). In archaeology, this imbalance manifests in senior roles within academia and professional practice (Hamilton 2014: 1-9). How does such gender imbalance within the discipline affect the construction of knowledge and, in particular, the representation of women and the interrogation of gender in the past (Conkey \& Gero 1997; Gilchrist 1999)? This question is addressed here by analysing 'The Oxford Handbooks of Archaeology' series as an index for gender imbalance in authorship. These volumes are commissioned as 'go-to' guides for students and professionals that make, shape and capture the state-of-the-art in the discipline. Ten handbooks from a wide chronological, thematic and geographic range are considered: Archaeology (Gosden et al. 2009), Anglo-Saxon archaeology (Hinton et al. 2011), Ritual and religion (Insoll 2011), North American archaeology (Pauketat 2012), African archaeology (Mitchell \& Lane 2013), European Bronze Age (Fokkens \& Harding 2013), Death and burial (Stutz \& Tarlow 2013), Neolithic Europe (Fowler et al. 2015), Later medieval archaeology (Gerrard \& Gutiérrez 2018) and Childhood (Crawford et al. 2018) (Figure 1). For balance, potential gender disparity in authorship is also assessed within three journals of medieval archaeology published in France, Britain and Italy (Figure 2). For multi-authored papers, all authors were included in the analysis.

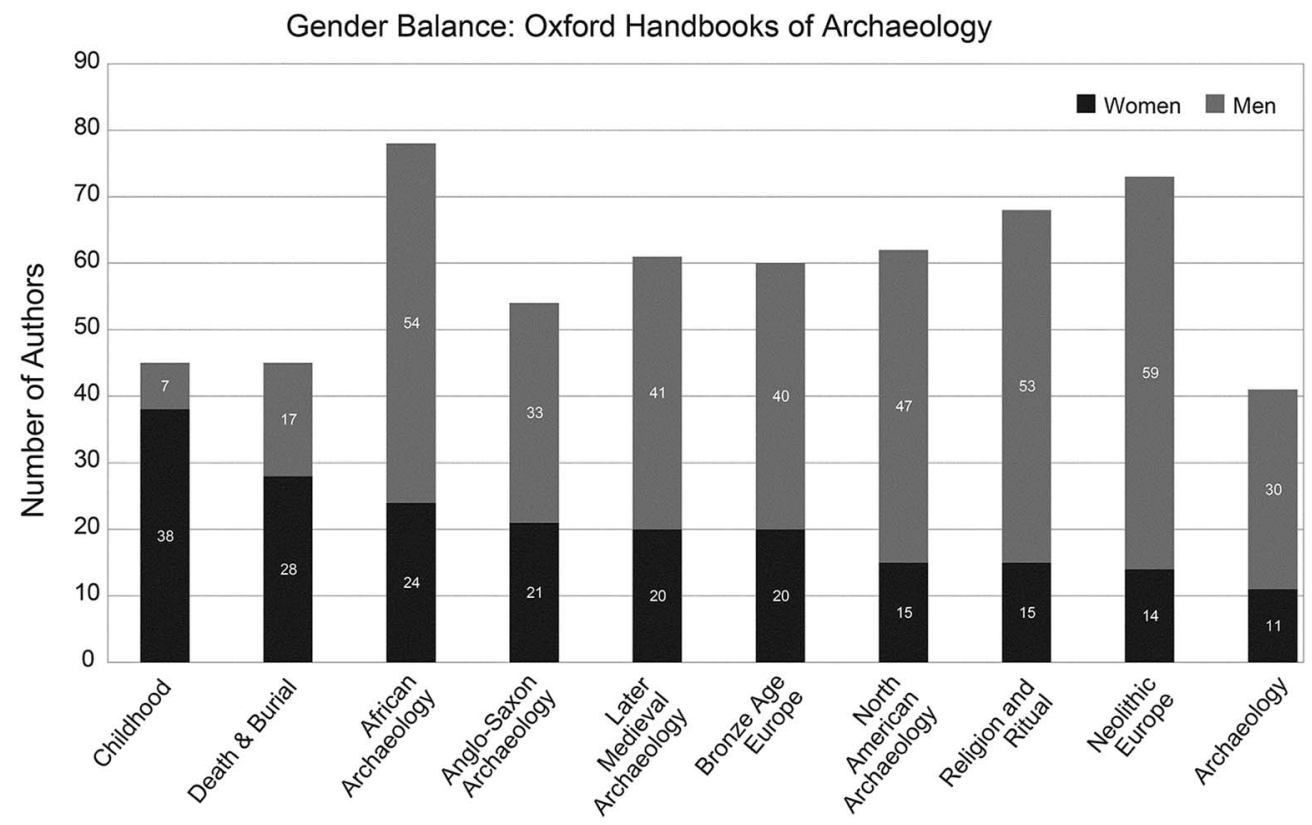

Selection of Handbooks

Figure 1. Gender balance in a selection of Oxford handbooks of archaeology (figure by the author).

(C) Antiquity Publications Ltd, 2019 
Men dominate the authorship in eight of the ten handbooks (Figure 1). Based on their public profiles, the authors presented as overwhelmingly white (over 95 per cent) in all publications. The gender disparity of the handbooks only somewhat contrasts with the three medieval archaeology journals (Figure 2). In the Oxford handbook of later medieval archaeology (Gerrard \& Gutiérrez 2018), for example, there are twice as many male authors as female authors. In the section on 'Power and display', all five chapters are by men. In contrast, six of the nine papers in the 'Growing up and growing old' section are by women (66 per cent). The message for medieval archaeologists is that women = nurture/care, and men = power. In Ritual and religion there were only 15 female authors in contrast with 53 male. Women outnumber male authors in only two of the handbooks: Childhood and Death and bur$\mathrm{ial}$. These comparisons are revealing in relation to contemporary gender roles: today, women are largely responsible for the primary care of children and elderly people. World religionsorganised or otherwise-still exclude women from roles as ritual specialists. While power and display are explicit themes in many of the Oxford handbooks, gender is not. The discussions therefore only account for an assumed and projected heteronormative past, and anything beyond the 'normative' is unexplored, including Queer or LGBTQ+ perspectives.

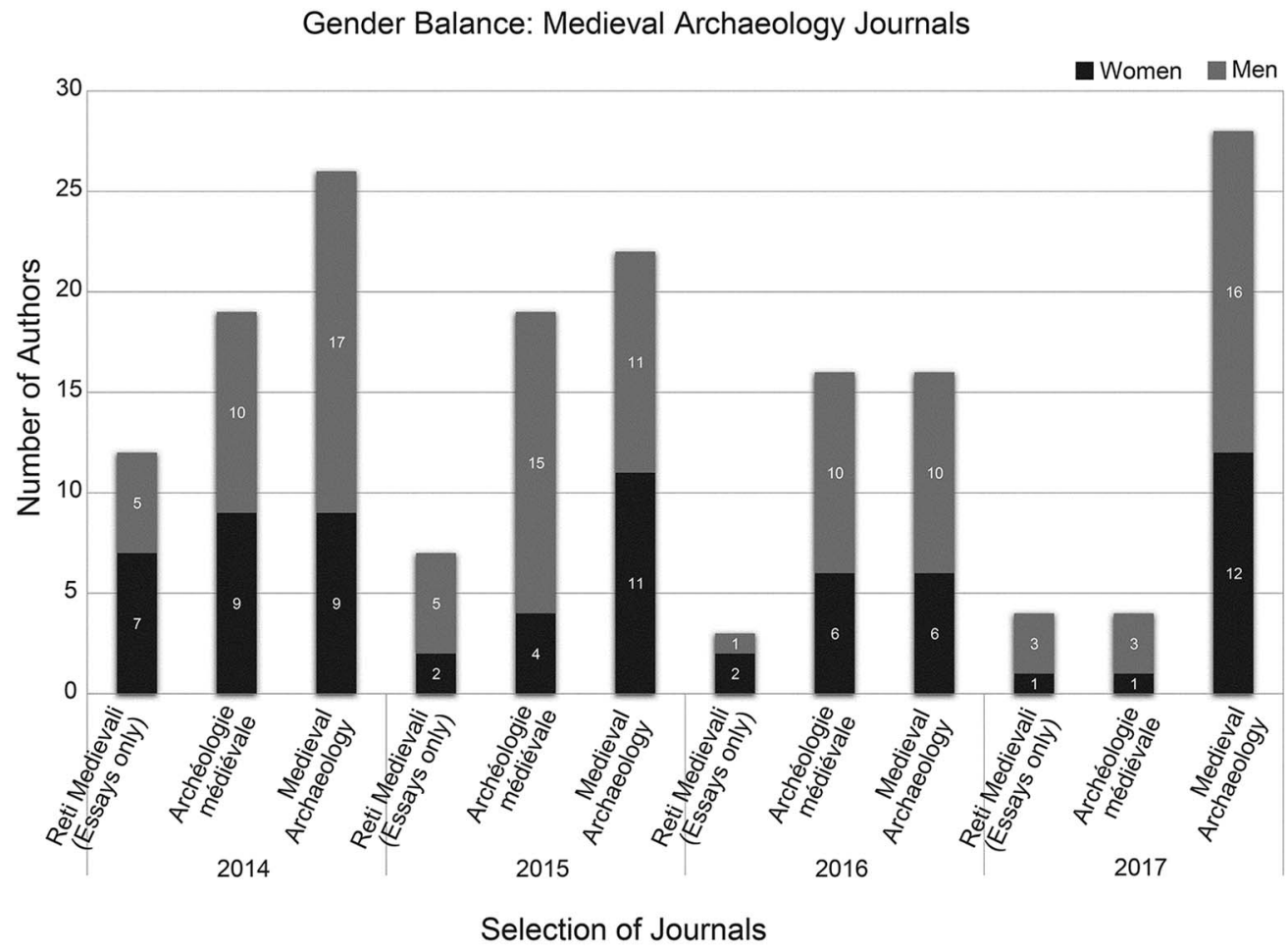

Figure 2. Breakdown of gender balance in three medieval archaeological journals: Reti Medievali, Archéologie médiévale and Medieval Archaeology 2014-2017 (figure by the author).

It could be argued optimistically that the discipline has 'mainstreamed' gender or, in other words, that gender has been embedded in wider interpretation and no longer requires explicit

(C) Antiquity Publications Ltd, 2019 
discussion. This, of course, is precisely the problem: a particular gendered ideology is implicit throughout many archaeological texts - that of the lives and practices of white, able-bodied heterosexual men. This means that many archaeologists, not just men, write about what is effectively the modern status quo. Not all men, of course, write exclusively about other men, or use masculinist perspectives; nor are all people with different gendered identities, including women, interested in writing about females, disenfranchised or underrepresented people. Yet it remains the case that women and all those who fall outside the 'mainstream' category of the white, heteronormative male are noticeably absent from the narrativeboth as topics for discussion and as authors.

The question is: does this matter? Do we need more diversity in authorship in order to see more diversity in the past? I argue that this is imperative. Embracing different and diverse voices would enhance our understanding of both the past and the present. It is unlikely that people would openly oppose this sentiment, but the evidence suggests that we still fall short of achieving these aims. We must ask then: who is responsible for ensuring that we have diverse representation? The answer is, of course, all of us. Together, we must strive to include others. We must all be reflective and conscious of what choices we make in relation to our archaeological practice; who is represented, as well as underrepresented, and who is affected. There is, however, a special onus on those 'gatekeepers' who control or influence archaeological discourse to be as inclusive as possible (Ahmed 2012). This means actively addressing these disparities. It may also mean asking difficult questions or refusing to participate in an event or publication that lacks fair representation, while recognising that, despite best efforts, such editorial balance can be difficult to achieve (Gerrard \& Gutiérrez pers. comm.).

While this article focuses on gender inequality and feminism, the wider "matrix of domination", which reinforces structural inequalities especially with regard to racism, must be acknowledged (Collins 2000: 227). It is noted that the majority of authors were white males, and where women are included, they are also predominately white. It is hypocritical to argue for the greater inclusion of (white) women while ignoring the structural inequalities that result in the exclusion of people of colour-especially women of colour, indigenous people and trans and gender-non-conforming people. We must be careful not to forget (or deny) the inherently patriarchal structure of academia and the colonial origins of archaeology as a discipline (Gosden 2004; Kim 2017). A broad-brush analysis of race, class, sexual orientation and ethnicity, however, is not attempted here, as these require detailed attention in their own right (Franklin 2001). Racism, for example, exists and must be challenged in our discourses. A positive shift to address this-particularly within the disciplines of medieval history and literature-is the emerging field of 'Global Middle Ages', which foregrounds studies of 'Race and racism' and decolonises the Middle Ages as a Eurocentric idea (Heng 2011; Kim 2017; Montón-Subías \& Hernando 2018).

\section{Gendered archaeologies}

The twenty-first century has witnessed an increasing acceptance that gender is fluid, nonbinary and non-normative (Gosling 2018). Gender differences are socially constructed, historically contingent and changing. For millennia, people have (re)negotiated context-specific

(C) Antiquity Publications Ltd, 2019 
gendered roles and other aspects of their identities involving ethnicity, sexuality and age. Awareness of this is evidenced by examples of gendered archaeologies (e.g. Tringham 1991; Gilchrist 1999; Sørenson 2000; Brück 2009), as well as archaeologies of sexuality

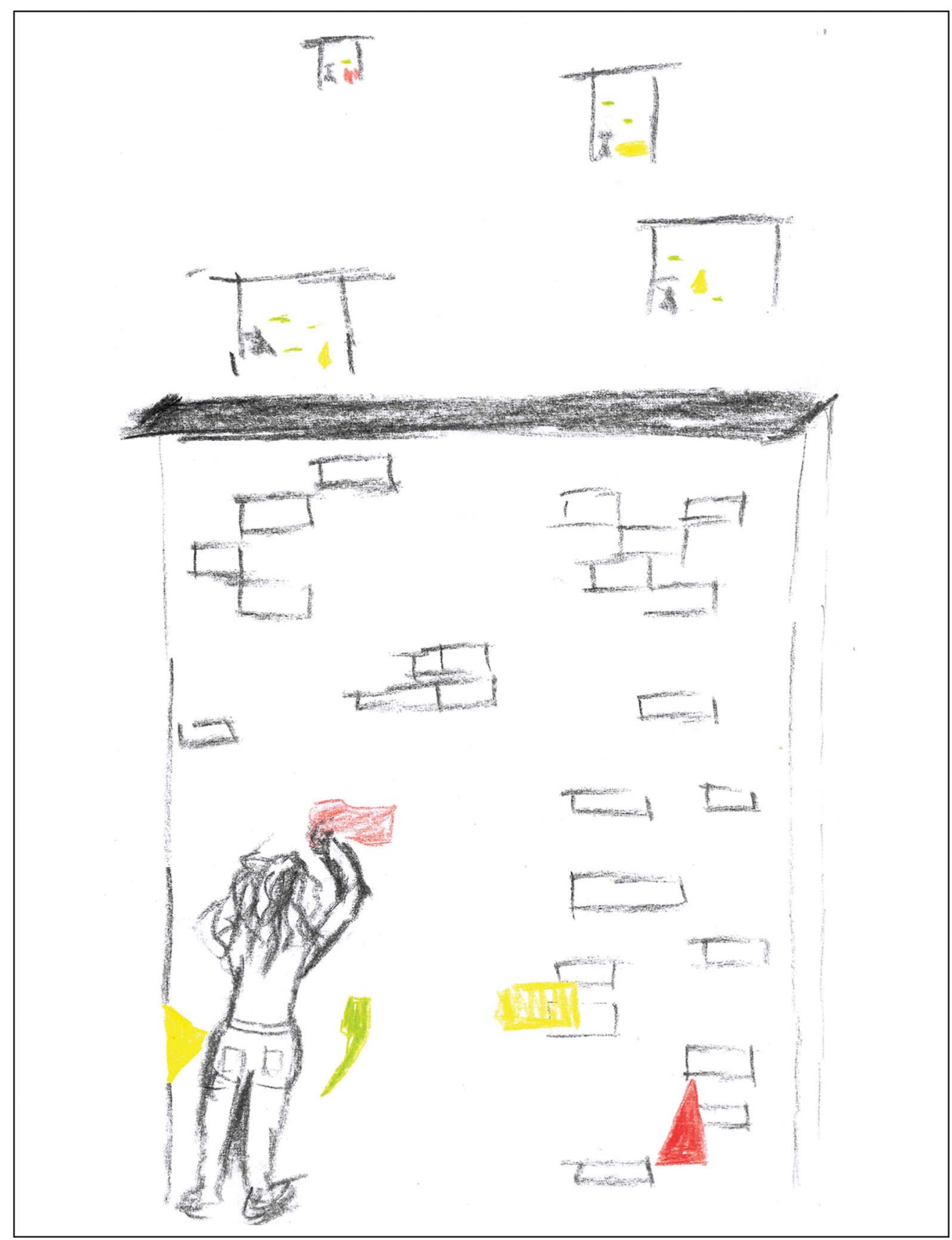

Figure 3. 'Filling in the gaps': an outdated approach (image by the author).

(C) Antiquity Publications Ltd, 2019 
(Voss 2008). Yet there remains a resistance (or an apathy) towards more broadly incorporating the ways that scholars have created, assembled and reinforced gender roles into archaeological accounts of the past. It is telling that there is no 'Oxford handbook of gender archaeology', and studies that offer insights into what women and other gendered identities did in the past are still rare (Dowson 2000; Voss 2000, 2008; Ghisleni et al. 2016). Problematically, gender-inclusive archaeologies often consist of 'filling in the gaps' of past narratives (Figure 3); this approach, however, fails to critique the gendered assumptions on which pre-existing interpretations were based (see Tringham 1991: 94). Also, the projection into the past of gendered ideologies based upon heteronormative family units is rarely challenged, although there are some exceptions; these include that of Reeder (2000), who advanced the (contested) idea of a homosexual relationship to explain depictions of two Egyptian elite males within their shared tomb (c. $2300 \mathrm{BC}$ ). This raises important questions: are scholars afraid that studies of gender, women or those who existed outside mainstream 'normative' society are not 'acceptable' within the Establishment? Can we attribute the paucity of gender research to anxieties about what is valued by the Academy? Are we reifying power dynamics in our scholarship that are more revealing of the sexual politics of our world than those of the past (Conboy et al. 1997: 2)?

\section{Gender and medieval archaeology in Britain and Ireland}

The paucity of research into gendered identities in the medieval past is difficult to comprehend. It seems that the closer we come to the white-washed, heteronormative and patriarchal 'modern world' (of Europe), the harder it is to imagine an alternative past. In the context of medieval European archaeology, this may be because the medieval past can seem so familiar that it is easy to assume that we already know it intimately. We know people's names, the places they lived, the words they wrote down, the plays they watched, the songs they sang, the fields they worked, and we have some of the things that they used, loved and cared about. Furthermore, modern religions still retain and perform certain aspects of their cosmology.

The material culture of late medieval Britain and Ireland is incredibly rich. Funerary monuments and effigies offer insights into mortuary practices and representations of the dead, while architecture provides a material context embodied with gender relations and domestic tensions (Figure 4). Literary texts and images are a rich source for representations of rituals surrounding belief and devotion, but also of daily life and the gendered aspects of book ownership (Figure 5). The design, production, use and decommissioning of objects, such as ceramics and metalwork, further inform our understandings (Figure 6-7). Interweaving these 'data' with our investigations of social relations demonstrates how the archaeological record — in the widest interpretation of that term—can be used to tell less fragmentary stories about the gendered lives of medieval people.

Given the richness of our sources, it is curious that inclusive studies are not more common in medieval archaeology. Why are other disciplines-particularly medieval history and literaturecapable of exploring individual agency, social relations and the lived experiences of medieval men and women? (e.g. Woolgar 1999; Gee 2002; Nolan 2009; Martin 2012; Moss 2012; Jasperse 2017; Delman 2019). Key themes addressed in these cognate disciplines are sponsorship (patronage) and religious devotion among elite women, while non-elites, such as washerwomen, maidservants, midwives and prostitutes, feature somewhat less (Rawcliffe 2009; Müller 2013).

(C) Antiquity Publications Ltd, 2019 


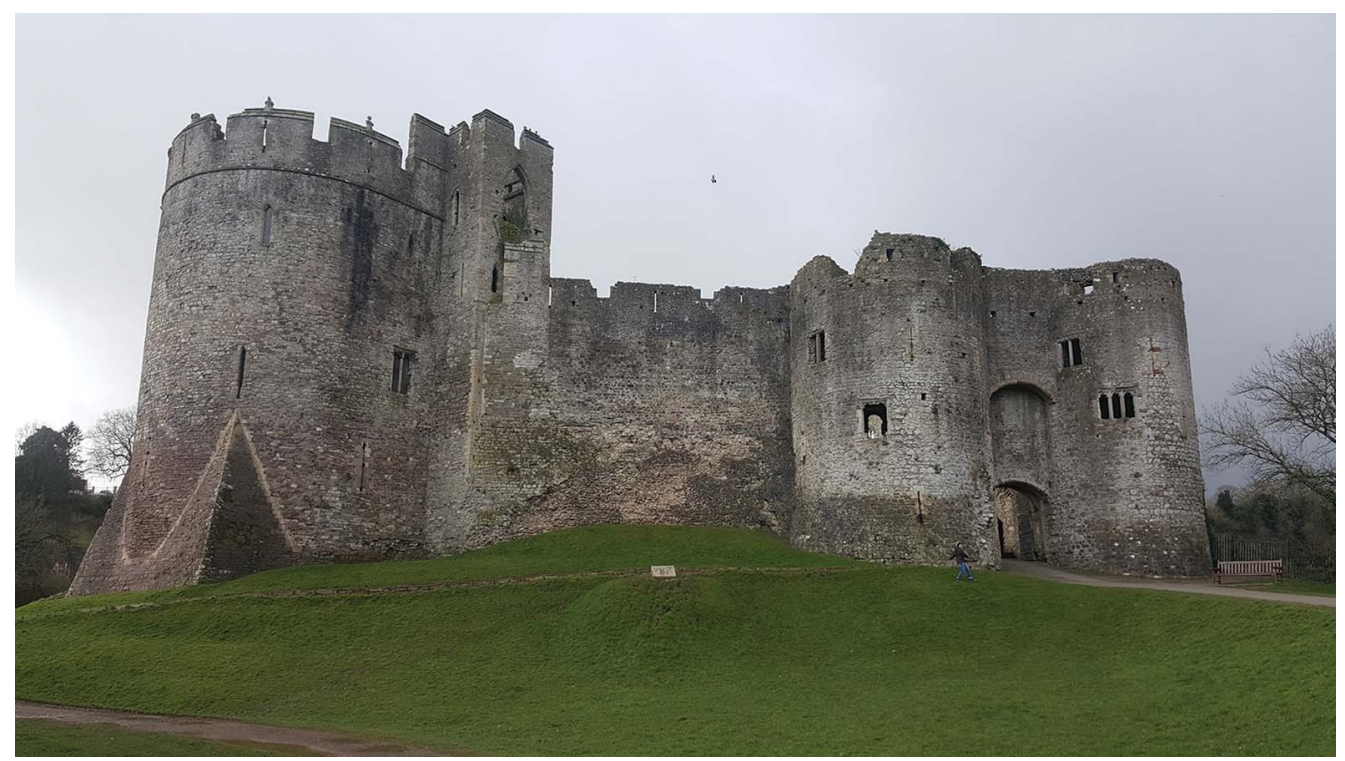

Figure 4. Chepstow Castle in Wales (photograph by the author).

These disciplines, however, still show an explicit awareness of the complex ways in which medieval people constructed their identities. This has resulted in innovative explorations of sexuality, the body, gendered identities, queerness and, of course, women and feminist activism (e.g. Green 2008; L'Estrange 2008; French 2013; Maude 2014; Moss 2018).

The absence of these approaches is keenly felt in the study of later medieval archaeology, which remains shaped by the predominance of androcentric (male-biased) perspectives. Gilchrist (1991) first examined inequality in the practice and discourse of archaeology in Britain, later demonstrating how a gendered archaeological approach could reveal a more complex story of the past (Gilchrist 1994, 1999, 2012). Beyond Gilchrist's scholarship and work by Johnson (2002), Giles (2007, 2014) and Graves (2007), there has been an apparent resistance to the types of social approaches, such as embodiment, materiality or phenomenology, that have been employed in prehistoric studies (e.g. Cooney 2000; Brück 2009; Carlin 2018). Except in rare instances (e.g. Gilchrist 2012; Robb \& Harris 2013), archaeologies of the life course and the body have largely been neglected. Studies that include Queer theory (Dowson 2000; Voss 2000; Ghisleni et al. 2016) are absent. Gendered interpretations that explore LGBTQ+ perspectives are non-existent and very rare across archaeology more generally. While some publications do foreground 'gender' - a malapropos for the study of women - these largely tell stories of women in the male world (Standley 2008, 2016; Hicks 2009; Richardson 2012; Wiekart 2014; Collins 2018). With few exceptions, this perceived disinterest in gender contrasts with early medieval, Anglo-Saxon and Viking studies, in which these subjects are explored to some extent (e.g. Lucy 2011; Poole 2013; O’Sullivan 2015). Is this indifference a reflection of unconscious bias in scholarly research or a conscious effort to reinforce a particular status quo? Gendered differences are manifest in both past and present, and the absence of attention to the performance of gender is therefore startling.

(C) Antiquity Publications Ltd, 2019 


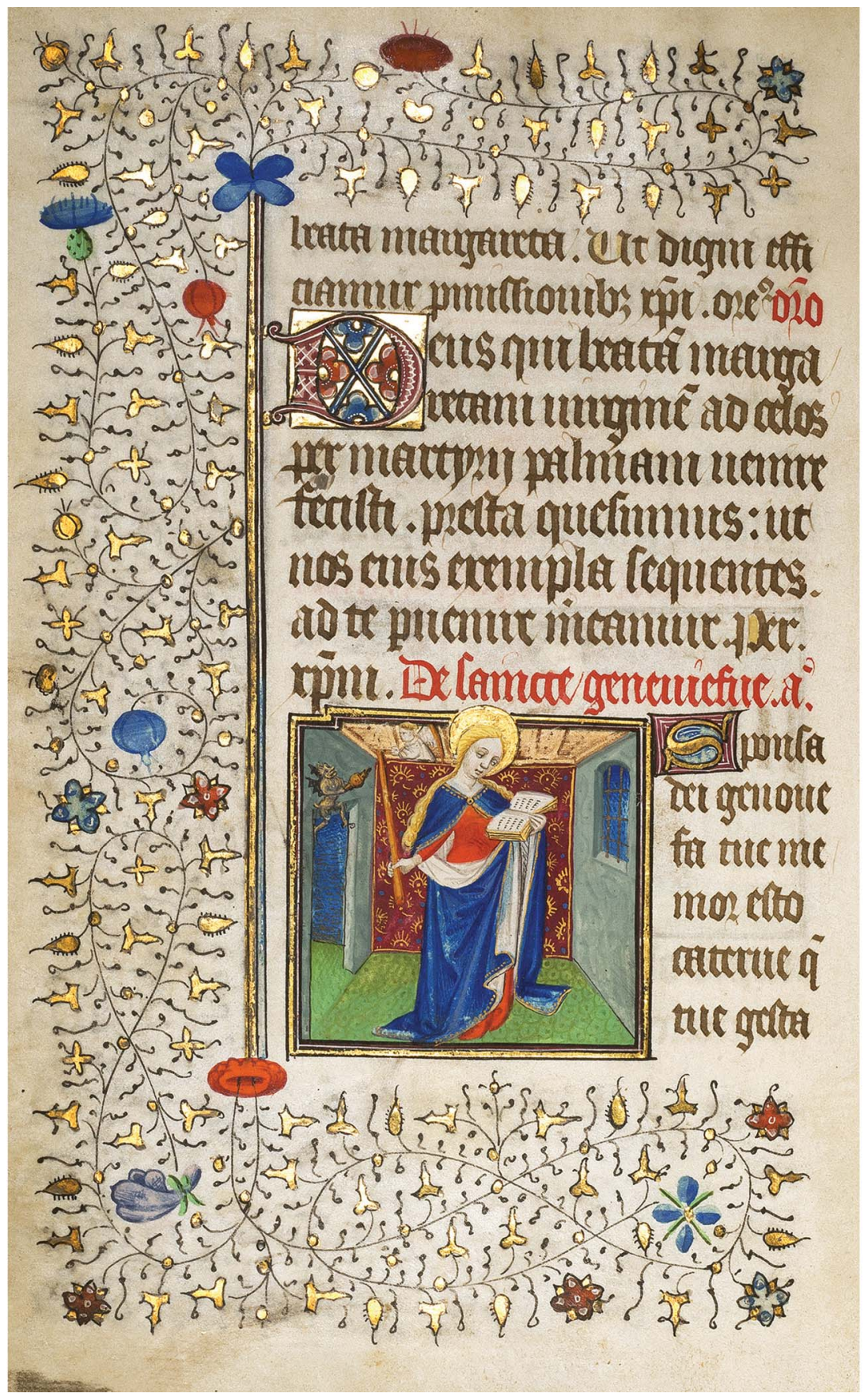

Figure 5. Detail of St Genevieve in MS 2087 Book of Hours (courtesy of University of Reading Special Collections). 


\section{Karen Dempsey}

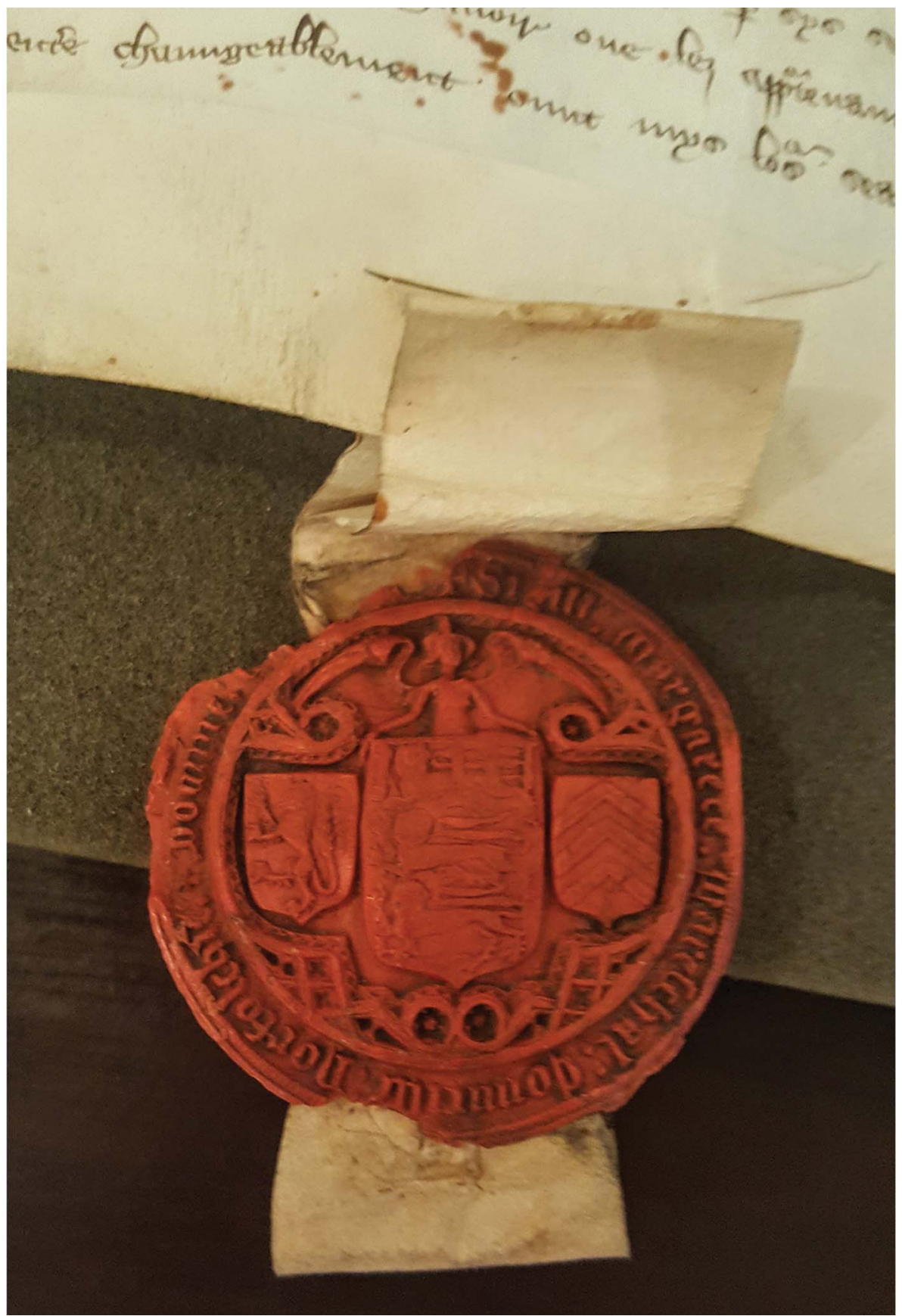

Figure 6. Seal of Margaret Mareschall, Countess of Northfolch and Lady Segrave (photograph by the author, courtesy of Charlotte Berry, Magdalen College, Oxford).

(C) Antiquity Publications Ltd, 2019 


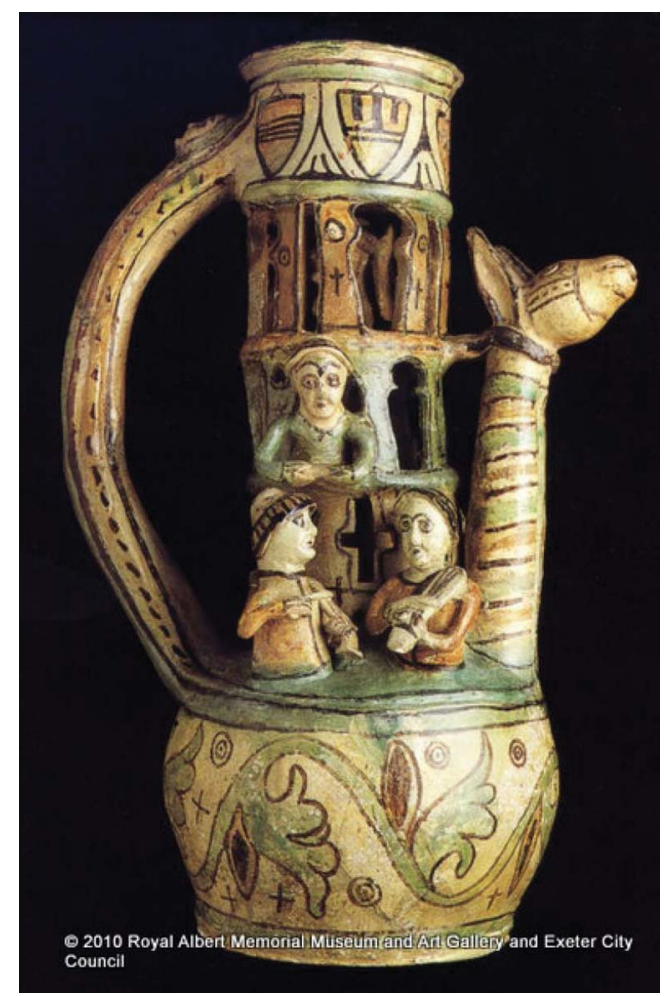

Figure 7. Exeter puzzle jug (courtesy of Royal Albert Memorial Museum and Exeter City Council).

\section{Gender and castle studies: the missing link}

Understanding the issues in relation to gender within castle studies requires some reflection; while this article does not provide a full historiography of castle studies, brief commentary is necessary (Barry 2008; O'Conor 2008; Creighton 2009; Hansson 2009). As with archaeology more generally, castle studies requires an interdisciplinary approach to explore the past in full; the application of necessary methods, however, has been limited. Nonetheless, the field has undergone a profound transformation over the past three decades, moving away from military frameworks (Allen Brown et al. 1963) and embracing deeper explorations of space and place. New approaches have emerged that focus on the symbolic meaning of castles and explore what these buildings might have meant to the medieval person. The emphasis has shifted from simply recounting detailed architectural descriptions towards integrated, interpretative approaches that view the spatial arrangement of buildings as a reflection and enactment of cultural ideologies (e.g. Coulson 1976; Heslop 1991; Fairclough 1992; Gilchrist 1999; Marshall 2002; Richardson 2003; Mol 2011; O’Keeffe 2015). Subsequently, a new wave of castle studies operating at a landscape-scale have looked beyond the masonry buildings to propose that the castle was only one part of a seigneurial package. This complex comprised many features, including dovecotes, villages, earthworks, water features and farms, through which to display, enhance and manage lordly economic, political and cultural authority (Hansson 2006; Creighton \& Liddiard 2008). This shift in approach represents a reaction against longstanding essentialist arguments based on binary oppositional understandings: military vs domestic, and defence $v$ s display. The debates that ensued resulted in a more critical discourse and an acknowledgement that castles served multiple roles (Johnson 2002; Speight 2004; Liddiard 2005; Creighton \& Liddiard 2008).

While these methodologies were at one time beneficial, they are now problematic. Landscape studies are based on macro-scale approaches that concentrate on displays of power, economic production, ecological exploitation and diet (Liddiard 2005; Creighton 2009; O'Conor et al. 2012; Swallow 2014; Beglane 2015). They rarely, however, address the microscale of daily life, or other issues such as gender, sexuality, emotion and the life course. Castle studies has not yet fully embraced social archaeology. While spatial approaches have been a

(C) Antiquity Publications Ltd, 2019 
key focus for archaeologists and architectural historians for two decades, they have not brought us any closer to understanding how people occupied these spaces. Interpretations of the spatial arrangement of buildings remain heavily influenced by perspectives of masculine rationality (Boys 1998). Buildings are thought to have a 'grammar' to be 'read' (Johnson 2002). Medieval use of space is still characterised and debated through dualistic binaries: public $v s$ private, sacred $v s$ profane, military $v s$ domestic and male $v$ s female, thus reinforcing oppositional understandings of man $v s$ women, self $v s$ other, subject $v s$ object. This culture of dualisms stems from androcentric thinking, in which man is the beneficiary. In other words, the male 'subject' is viewed as active, rational and powerful, the female 'object' is emotional, passive and can be exploited.

While we can demonstrate that medieval society was highly stratified and that social space and interaction were regulated (Gilchrist 1999; Hannson 2009), there remains an onus on the gender scholar to prove that matters are anything other than male. Buildings may be thought of as active agents, but often only in terms of masculine power, wealth and status. Women, in this model, are determined as passive, secluded 'objects', excluded from the 'location of power', which is a male or masculine space (Johnson 2002). If this view is accepted, then one could safely assume that this exclusion had a physical manifestation in the form of a particular set of rooms from which women were excluded or secluded within. Yet, confusingly, the idea of 'female space' in the castle is persistently resisted, despite their obvious and tangible presence. Goodall (2011:21) contends that women and children were entirely absent from castles, and that medieval elite households were celibate and male. Even if this were true, why are homosocial behaviours (Moss 2018), performances of masculinities or potential male homosexual relations not explored in this scenario?

Our current view of the later medieval period typically comprises buildings, objects and landscapes often detached from each other. Discussions of castles have not yet combined people, places and things together within their historical context. Architecture has a much richer role to play in archaeological interpretation than as a passive reflection of human behaviour, or as a binary didactic instrument, containing or transmitting social cues. Architecture must be examined in terms of lived experience and as material culture. While some scholars do concentrate on the latter, it is often analysed in a typological or scientific manner-especially pottery — and not contextualised spatially within the castle (e.g. Creighton \& Wright 2016). People are mostly discussed in terms of power, as patrons or ruling lords; in other words, elite males or females who operated as such. Taken together, these traits reveal the discipline's lack of enthusiasm to engage in meaningful discourses about biographies, life cycles, social practices, beliefs and identities.

One key issue is that castle studies remains a male-dominated field. Despite the 'new wave' of such studies moving beyond militarism, it still typically reproduces male-centred interpretations epitomised by a focus on political power or status. Studies that focus on women often endeavour to insert the female into 'traditionally' male activities, rather than creating a narrative of the female experience of living in the medieval world (e.g. Richardson 2012). This is problematic, as it results in 'male qualities' being prioritised in analyses of social activities. There is no doubt that castles and associated activities have been long viewed as male, where metonyms for masculinity comprised weapons, armour and horses (Gilchrist 1999: 121). Generally, castle scholars no longer explicitly depict the castle as an aggressively

(C) Antiquity Publications Ltd, 2019 
male-only world of sweat and testosterone; the current, insidious 'gender-blindness' within castle studies, however, ensures the preservation of this now implicit ideology. Women, and those who were (or are?) not accepted as part of mainstream society, are absent(ed)—figuratively and literally. It seems that the discipline is focused on maintaining a particular status quo in the present by projecting 'known' gender constructs and roles onto the past, thereby ignoring other possibilities (Conkey \& Spector 1984).

Ideally, castle studies would foreground human-centred stories that emphasise the real complexities of everyday life, where - as today - the world is experienced through the spectrum of human emotions. My current Marie Skłodowska-Curie Fellowship, 'HeRstory', aims to achieve this by focusing on 12 castles as case studies across Ireland, Britain and France. Crucially, it integrates people, places and things, and asks new questions of the archaeological evidence, such as: how was gender constructed and mediated in relation to the medieval castle? What was it like to be a person, other than an elite male, living in the medieval castle? What material and social practices shaped the world of the castle? The inclusion of gendered interpretations is a fundamental issue not just for castle studies, but also for medieval archaeology and archaeology more generally, where many scholars still take a singular view of the past: that of able-bodied, heterosexual men of power-in other words, the modern 'masculine' status quo.

\section{Conclusion}

Archaeology reinforces or projects a real and mythologised patriarchal hierarchy within its scholarship. Consistently endorsing male authors, male perspectives and male stories, it perpetuates the idea of 'male activities' as superior. This affects not only our understanding of the past, but also maintains the patriarchal status quo in the present. If a male-oriented narrative is dominant and represented in scholarship, and it is embedded within a patriarchal academy that reinforces androcentrism, then archaeological (or other) evidence that speaks to the contrary will continue to be overlooked or disregarded. Our discourses must create multi-vocal narratives that reveal the social complexities and diversity of the world. In an era of global feminist activism, it is no longer acceptable to portray the past through one master narrative that consistently ignores the lives and experiences of othered people, especially women and those who do not conform to the heteronormative or white Eurocentric 'ideal'. This means moving away from accepting or assuming binary and heteronormative notions of the past.

Our scholarship needs to stop identifying gender - especially in attempting to make women visible - and to acknowledge that gender is already there. Rather than "add women and stir" (Tringham 1991: 94), we need to weave a new story, reimagining all the threads of various elements of past identities and social relations, and the wide spectrum of gendered identities, to form a rich tapestry of the past and the present that constructs it (Figure 8). If we remain complacent to the current gender (and racial) disparity, we are complicit in reinforcing the unequal status quo, and we fail to reach a large part of the potential audience for archaeology—those who feel disenfranchised by patriarchal, heteronormative or colonial narratives.

While we now accept that our ways of being in the present inform how we view and interpret the past, many scholars are unable (or unwilling?) to discuss their personal motivations for

(C) Antiquity Publications Ltd, 2019 


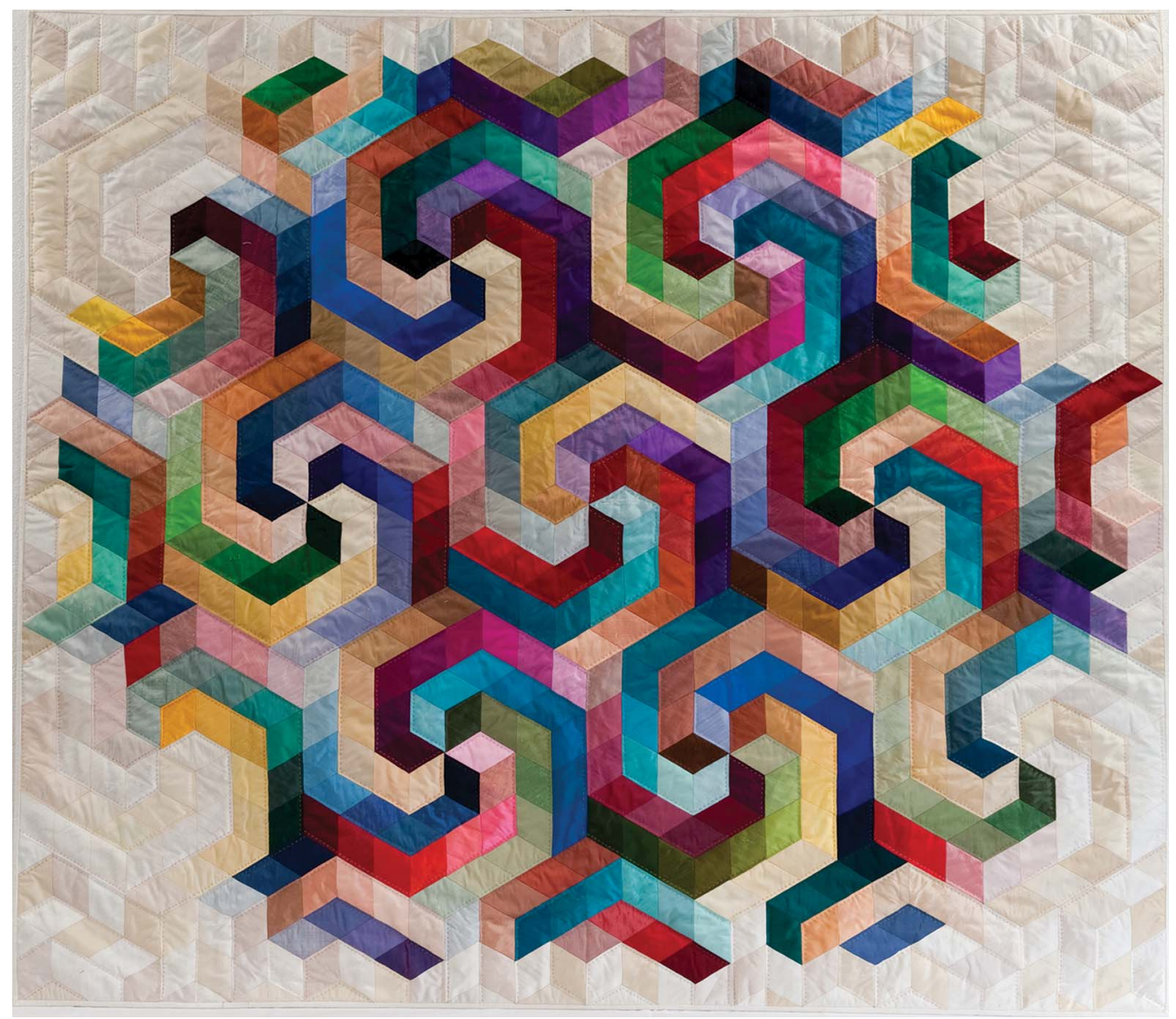

Figure 8. Imagining the past as a textile: 'Entwined' (image courtesy of Jill Sharpe).

choosing a particular interpretative approach. The lack of reflection given to the author's personal perspective in many archaeological studies is a core issue in how structural inequalities endure, including the perpetuation of patriarchal approaches. Discrimination today based on sex, gender or sexual orientation is intrinsically linked to the paucity of research on gender in the past. To combat this, we must all demonstrate who we are and why we 'do' our studies in our own particular way. To paraphrase Virginia Woolf, this means changing and adapting, re-arranging our rooms (physical, literal and digital) to encourage other people to take up and redefine that space in order to enable a diverse, multi-vocal archaeology.

\section{Acknowledgements}

This project has received funding from the European Union's Horizon 2020 research and innovation programme under grant agreement number 74606. Thanks to Neil Carlin, Daisy Black and Aleks Pluskowski for commenting on this article. A very special thanks to Roberta Gilchrist for assistance and constructive comments. This article adds to the conversation she initiated in Antiquity in 1991. 


\section{References}

Aнmed, S. 2012. On being included: racism and diversity in institutional life. Durham (NC): Duke University Press. https://doi.org/10.1215/9780822395324

Allen Brown, R., H.M. Colvin \& A.J. TaYlor BRown. 1963. The history of the king's works. London: Her Majesty's Stationery Office.

BARRY, T. 2008. The study of Irish medieval castles: a bibliographic survey. Proceedings of the Royal Irish Academy 108(C): 115-36.

https://doi.org/10.3318/PRIAC.2008.108.115

Beglane, F. 2015. Anglo-Norman parks in medieval Ireland. Dublin: Four Courts.

Boys, J. 1998. Beyond maps and metaphors? Rethinking relationships between architecture and gender, in R. Ainley (ed.) New frontiers of space, bodies and gender: 203-17. London: Routledge.

BRÜCK, J. 2009. Women, death and social change in the British Bronze Age. Norwegian Archaeological Review 42: 1-23. https://doi.org/10.1080/00293650902907151

Carlin, N. 2018. The Beaker Phenomenon? Understanding the character and context of social practices in Ireland 2500-2000 BC. Leiden: Sidestone.

Coluns, P.H. 2000. Black feminist thought: knowledge, consciousness, and the politics of empowerment. London: Routledge.

Collins, T. 2018. Archaeologies of female monasticism in Ireland, in E. Campbell, E. Fitzpatrick \& A. Horning (ed.) Becoming and belonging in Ireland $A D$ c. 1200-1600: essays in identity and cultural practice: 69-87. Cork: Cork University Press.

Conboy, K., N. Medina \& S. Standboy (ed.). 1997. Writing on the body: female embodiment and feminist theory. New York: Columbia University Press.

Conkey, M.W. \& J. Gero. 1997. Programme to practice: gender and feminism in archaeology. Annual Review of Anthropology 26: 411-37. https://doi.org/10.1146/annurev.anthro.26.1. 411

Conkey, M.W. \& J. Spector. 1984. Archaeology and the study of gender. Advances in Archaeological Method and Theory 7: 1-9.

Cooney, G. 2000. Landscapes of Neolithic Ireland. London: Routledge.
Coulson, C. 1976. Structural symbolism in medieval castle architecture. Journal of the British Archaeological Association 132: 73-90.

Crawford, S., D. Hadley \& G. Shepherd (ed.). 2018. The Oxford handbook of the archaeology of childhood. Oxford: Oxford University Press. https://doi.org/10.1093/oxfordhb/ 9780199670697.001 .0001

Creighton, O. 2009. Castle-studies and the European medieval landscape: traditions, trends and future research directions. Landscape History 30(2): 5-20.

https://doi.org/10.1080/01433768.2009. 10594605

Creighton, O. \& R. Liddiard. 2008.

Fighting yesterday's battle: beyond war or status in castle-studies. Medieval Archaeology 52: 161-69. https://doi.org/10.1179/174581708x335477

Creighton, O.H. \& D.W. Wright. 2016. The anarchy: war and status in $12^{\text {th }}$-century landscapes of conflict. Liverpool: Liverpool University Press. https://doi.org/10.5949/liverpool/ 9781781382424.001 .0001

Delman, R.M. 2019. Gendered iconography, childbirth, and female authority in Alice Chaucer, Duchess of Suffolk's residence at Ewelme, Oxfordshire. Journal of Medieval History 45. https://doi.org/ 10.1080/03044181.2019.1593619

Dowson, T.A. 2000. Why queer archaeology? An introduction. World Archaeology 32: 161-65. https://doi.org/10.1080/00438240050131144

European Commission. 2008. Mapping the maze: getting more women to the top in research.

Luxembourg: Office for Official Publications of the European Communities.

FAIrCloUgh, G. 1992. Meaningful constructions -spatial and functional analysis of medieval buildings. Antiquity 66: 348-66. https://doi.org/10.1017/S0003598X00081461

FoKkENs, H. \& A. Harding (ed.). 2013. The Oxford handbook of the European Bronze Age. Oxford: Oxford University Press. https://doi.org/10.1093/oxfordhb/ 9780199572861.001 .0001

Fowler, C., J. Harding \& D. Hofmann (ed.). 2015. The Oxford handbook of Neolithic Europe. Oxford: Oxford University Press. https://doi.org/10.1093/oxfordhb/ 9780199545841.001 .0001

(C) Antiquity Publications Ltd, 2019 


\section{Karen Dempsey}

Frankin, M. 2001. A Black feminist-inspired archaeology? Journal of Social Archaeology 1: 108-25. https://doi.org/10.1177/146960530100100108

FRENCH, K.L. 2013. The good women of the parish: gender and religion after the Black Death. Philadelphia: University of Pennsylvania Press.

GeE, L.L. 2002. Women, art and patronage from Henry III to Edward III, 1216-1377.

Woodbridge: Boydell.

Gerrard, C. \& A. Gutiérrez (ed.). 2018. The Oxford handbook of later medieval archaeology in Britain. Oxford: Oxford University Press. https://doi.org/10.1093/oxfordhb/ 97801987447719.001.0001

GiLchrist, R. 1991. Women's archaeology? Political feminism, gender theory and historical revisions. Antiquity 65: 495-501. https://doi.org/10.1017/S0003598X00080091

- 1994. Gender and material culture: the archaeology of religious women. London: Routledge.

- 1999. Gender and archaeology: contesting the past. London: Routledge.

- 2012. Medieval life: archaeology and the life course. Woodbridge: Boydell \& Brewer.

Ghisleni, L., A.M. Jordan \& E. Fioccoprile. 2016. 'Binary binds': deconstructing sex and gender dichotomies in archaeological practice. Journal of Archaeological Method and Theory 23: 765-87. https://doi.org/10.1007/s10816-016-9296-9

GILES, K. 2007. Seeing and believing: visuality and space in pre-modern England. World Archaeology 39: 105-21.

https://doi.org/10.1080/00438240601136470

- 2014. Ways of living in medieval England, in K. Giles \& M. Svart Kristiansen (ed.) Dwellings, identities and homes: European housing culture from the Viking Age to the Renaissance: 13-28. Aarhus: Aarhus University Press.

Goodall, J. 2011. The English castle. London: Palgrave Macmillan.

Gosden, C. 2004. Archaeology and colonialism: contact from $5000 \mathrm{BC}$ to the present. Cambridge: Cambridge University Press.

Gosden, C., B. Cunliffe \& R. Joyce (ed.). 2009. The Oxford handbook of archaeology. Oxford:

Oxford University Press.

https://doi.org/10.1093/oxfordhb/ 9780199271016.001.0001

GosLing, J. 2018. Gender fluidity reflected in contemporary society. Jung Journal 12(3): 75-79. https://doi.org/10.1080/19342039.2018.1479080
Graves, C.P. 2007. Sensing and believing: exploring worlds of difference in pre-modern England-a contribution to the debate. World Archaeology 39: 515-31. https://doi.org/10.1080/00438240701676276

Green, M.H. 2008. Gendering the history of women's healthcare. Gender \& History 20: 487-518. https://doi.org/10.1111/j.1468-0424.2008. 00534.x

Hamilton, S. 2014. Under-representation in contemporary archaeology. Papers From the Institute of Archaeology 24(1): p.Art. 24. https://doi.org/10.5334/pia.469

Hansson, M. 2006. Aristocratic landscape: the spatial ideology of the medieval aristocracy (Lund Studies in Historical Archaeology 2). Lund: Lund University Press.

-2009 . The medieval aristocracy and the social use of space, in R. Gilchrist \& A. Reynolds (ed.) Reflections: 50 years of medieval archaeology, 19572007 (Society for Medieval Archaeology Monograph Series 30): 436-52. Leeds: Maney.

Harley, S. 2003. Research selectivity and female academics in UK universities: from gentleman's club and barrack yard to smart macho? Gender and Education 15: 377-92. https://doi.org/10.1080/09540250310001610580

Heng, G. 2011. The invention of race in the European Middle Ages $1 \& 2$ : race studies, modernity, and the Middle Ages. Literature Compass 8: 315-31 \& 332-50.

Heslop, T.A. 1991. Orford Castle, nostalgia and sophisticated living. Architectural History 34: 36-58. https://doi.org/10.2307/1568593

Hicks, L. 2009. Magnificent entrances and undignified exits: chronicling the symbolism of castle space in Normandy. Journal of Medieval History 35: 52-69. https://doi.org/10.1016/j.jmedhist.2009.01.001

Hinton, D., S. Crawford \& H. Hamerow (ed.). 2011. The Oxford handbook of Anglo-Saxon archaeology. Oxford: Oxford University Press. https://doi.org/10.1093/oxfordhb/ 9780199212149.001 .0001

Insoll, T. (ed.). 2011. The Oxford handbook of the archaeology of ritual and religion. Oxford: Oxford University Press.

JASPERSE, J. 2017. Matilda, Leonor and Joanna: the Plantagenet sisters and the display of dynastic connections through material culture. Journal of

(C) Antiquity Publications Ltd, 2019 
Medieval History 43: 523-47.

https://doi.org/10.1080/03044181.2017. 1378918

Johnson, M. 2002. Behind the castle gate: from medieval to renaissance. London: Routledge.

KIM, D. 2017. Teaching medieval studies in a time of white supremacy. Available at:

http://www.inthemedievalmiddle.com/2017/08/ teaching-medieval-studies-in-time-of.html (accessed 27 March 2019).

L'Estrange, E. 2008. Holy motherhood: gender, dynasty, and visual culture in the later Middle Ages. Manchester: Manchester University Press.

LIDDIARD, R. 2005. Castles in context: a social history offortification in England and Wales, 1066-1500. Bollington: Windgather.

Lucy, S. 2011. Gender and gender roles, in D. Hinton, S. Crawford \& H. Hamerow (ed.) The Oxford handbook of Anglo-Saxon archaeology: 688-703. Oxford: Oxford University Press.

Marshall, P. 2002. The great tower as residence in the territories of the Norman and Angevin kings of England, in G. Meirion-Jones, E. Impey \& $\mathrm{M}$. Jones (ed.) The seigneurial residence in Western Europe AD 800-1600: 27-44. Oxford: British Archaeological Reports.

MARTIN, T. (ed.). 2012. Reassessing the roles of women as 'makers' of medieval art and architecture. Leiden: Brill.

MAude, K. 2014. Citation and marginalisation: the ethics of feminism in medieval studies. Journal of Gender Studies 23: 247-61.

https://doi.org/10.1080/09589236.2014. 909719

Mitchell, P. \& P. Lane (ed.). 2013. The Oxford handbook of African archaeology. Oxford: Oxford University Press.

https://doi.org/10.1093/oxfordhb/ 9780199569885.001 .0001

Mol, E.M. 2011. Hidden complexities of the Frankish castle: social aspects of space in the configurational architecture of Frankish castles in the Holy Land, 1099-1291. Leiden: Leiden

University Press.

Montón-Subías, S. \& A. Hernando. 2018.

Modern colonialism, Eurocentrism and historical archaeology: some engendered thoughts.

European Journal of Archaeology 21: 455-71. https://doi.org/10.1017/eaa.2017.83

Moss, R. 2012. Planters of great civilitie: female patrons of the arts in late medieval Ireland, in
T. Martin (ed.) Reassessing the roles of women as 'makers' of medieval art and architecture: 275-308. Leiden: Brill.

Moss, R.E. 2018. Ready to disport with you: homosocial culture amongst the wool merchants of fifteenth-century Calais. History Workshop Journal 86: 1-21.

MüLLER, M. 2013. Peasant women, agency and status in mid-thirteenth- to late fourteenth-century England: some reconsiderations, in C. Beattie \& M.F. Stevens (ed.) Married women and the law in premodern Northwest Europe: 91-113. Woodbridge: Boydell.

Nolan, K. 2009. Queens in stone and silver: the creation of a visual imagery of queenship in Capetian France. New York: Palgrave Macmillan.

O'Conor, K. 2008. Castle-studies in Ireland-the way forward. Chatteau Gaillard 23: 329-39.

O'Conor, K., P. Naessens \& R. Sherlock. 2012. Rindoon Castle, Co. Roscommon: a border castle on the Irish Frontier. Chateau Gaillard 26: 313-23.

O'Keeffe, T. 2015. Medieval Irish buildings. Dublin: Four Courts.

O'Sullivan, J. 2015. Strung along: re-evaluating gendered views of Viking-Age beads. Medieval Archaeology 59: 73-86. https://doi.org/10.1080/00766097.2015. 1119384

Pauketat, T. (ed.). 2012. The Oxford handbook of North American archaeology. Oxford: Oxford University Press. https://doi.org/10.1093/oxfordhb/ 9780195380118.001 .0001

Poole, K. 2013. Engendering debate: animals and identity in Anglo-Saxon England. Medieval Archaeology 57: 61-82. https://doi.org/10.1179/0076609713Z. 00000000015

RawCliffe, C. 2009. A marginal occupation? The medieval laundress and her work. Gender \& History 21: 147-69. https://doi.org/10.1111/j.1468-0424.2009. 01539.x

Reeder, G. 2000. Same-sex desire, conjugal constructs, and the tomb of Niankhkhnum and Khnumhotep. World Archaeology 32: 193208.

https://doi.org/10.1080/00438240050131180 


\section{Karen Dempsey}

Richardson, A. 2003. Gender and space in English royal palaces $c$. 1160-c. 1547: a study in access analysis and imagery. Medieval Archaeology 47: 131-65. https://doi.org/10.1179/med.2003.47.1.131

- 2012. 'Riding like Alexander, hunting like Diana' gendered aspects of the medieval hunt and its landscape settings. Gender and History 24: 253-70. https://doi.org/10.1111/j.1468-0424.2012. 01681.x

Robb, J. \& O.J.T. Harris. 2013. The body in history: Europe from the Palaeolithic to the future. Cambridge: Cambridge University Press.

Sørensen, M.L.S. 2000. Gender archaeology. Cambridge: Polity.

Speight, S. 2004. British castle-studies in the late $20^{\text {th }}$ and $21^{\text {st }}$ centuries. History Compass 2: 1-32.

STANDley, E. 2008. Ladies hunting: a late medieval decorated mirror case from Shapwick, Somerset. The Antiquaries Journal 88: 198-206. https://doi.org/10.1017/S0003581500001396

- 2016. A handmaiden's yarn? The evidence for spinning and its social implications, c. 12001500. Medieval Archaeology 60: 266-99. https://doi.org/10.1080/00766097.2016. 1221264

Stutz, L. \& S. TARLow (ed.). 2013. The Oxford handbook of the archaeology of death and burial. Oxford: Oxford University Press. ttps://doi.org/10.1093/oxfordhb/ 9780199569069.001 .0001
Swallow, R. 2014. Gateways to power: the castles of Ranulf III of Chester and Llywelyn the Great of Gwynedd. Archaeological Journal 171: 291-314. https://doi.org/10.1080/00665983.2014. 11078268

Tringham, R. 1991. Households with faces: the challenge of gender in prehistoric architectural remains, in J.M. Gero \& M. Conkey (ed.) Engendering archaeology: 93-131. Oxford: Blackwell.

VAN DEN BRINK, M. \& Y. Benschop. 2012. Slaying the seven-headed dragon: the quest for gender change in academia. Gender Work and Organization 19: 71-92. https://doi.org/10.1111/j.1468-0432.2011. 00566.x

Voss, B. 2000. Feminisms, queer theories, and the archaeological study of past sexualities. World Archaeology 32: 180-92. https://doi.org/10.1080/00438240050131171

- 2008. Sexuality studies in archaeology. Annual Review of Anthropology 37: 317-36. https://doi.org/10.1146/annurev.anthro.37. 081407.085238

Wiekart, K. 2014. Place and prestige: enacting and displaying authority in English domestic spaces during the central Middle Ages, in S. Stull (ed.) From West to East: current approaches in medieval archaeology: 96-120. Newcastle: Cambridge Scholars.

Woolgar, C. 1999. The great household in late medieval England. London: New Haven.

Received: 8 June 2018; Revised: 30 October 2018; Accepted: 23 November 2018

(C) Antiquity Publications Ltd, 2019 